$\ll$ Review》

\title{
Carotenoids in Avian Nutrition and Embryonic Development. 1. Absorption, Availability and Levels in Plasma and Egg Yolk
}

\author{
P.F. Surai*, B.K. Speake and N.H.C. Sparks \\ Avian Science Research Centre, Auchincruive, Ayr, KA 65 HW, Scotland, UK
}

\section{Introduction}

Avian embryo development is associated with a progressive accumulation in certain tissues of lipids which are rich in polyunsaturated fatty acids (PUFA), making such tissues vulnerable to free radical attack and lipid peroxidation. Antioxidant systems are expressed in the embryonic tissues and are responsible for maintaining antioxidant protection during different stages of embryoonic development, in particular at hatching time when oxidative stress is highly pronounced (Surai, 1999). The antioxidant systems of the avian embryo are based on the antioxidant enzymes superoxide dismutase (SOD), glutathione peroxidase (GSH-Px) and catalase (Surai, 1999 a ; Surai, 2000 a), and fat-soluble and water-soluble natural antioxidants (Surai, 1999). Vitamin $\mathrm{E}$ is considered to be the main player in the antioxidant defence at the cellular and subcellular levels (Niki, 1996). In recent years it has become evident that in the cell the association of vitamin $\mathrm{E}$ with other natural antioxidants which are able to recycle this vitamin from its oxidized form is the major biochemical mechanism in maintaining the efficiency of antioxidant defence (Surai, 1999 ; Surai, 2000).

Different antioxidant components occupy distinct cellular and extracellular compartments and among them, active recycling plays a crucial role. For example, oxidized vitamin E (tocopheroxyl radical) has been shown to be regenerated by ascorbate, glutathione (GSH), lipoic acid, or ubiquinols. Furthermore glutathione disulfides (GSSG) can be regenerated by glutathione reductase and enzymic pathways have also been identified for the recycling of the ascorbate radical and dehydroascorbate. The reducing agents that are used to fuel these recycling reactions (NADH and NADPH) are ultimately derived from the oxidation of nutrients (Chan et al., 1999). The exact role of carotenoids within this system is still under discussion but evidence is accumulating concerning antioxidant properties of carotenoids and their role in antioxidant defence directly or via interactions with other antioxidants increasing their efficiency. In this respect, development of effective HPLC-based methods for carotenoid analysis, in association with the introduction of new assays for antioxidant activities in vitro, promise new advances in this area.

Received : July 28, 2000 Accepted : September 20, 2000

* Correspondence, Avian Science Research Centre, Scottish Agricultural College, Auchincruive, Ayr, KA6 5HW, e-mail : P.Surai@au.sac.ac.uk 
A historic perspective

Carotenoids, the most numerous and widespread group of pigments in nature, have had a long and interesting history. Studies on these pigments were started at the beginning of the 19th century, when the crystalline yellow pigment carotene was first isolated in 1831 by Wackenroder from carrots and the yellow pigments of autumn leaves were named as xanthophylls by Berzelius in 1837 (Tee, 1992 ; Karnaukhov, 1990). A hundred years later the number of known naturally occurring carotenoids was about 15 in 1933 and about 80 in 1948 and rose sharply to about 300 over the next 20 years (Ong and Tee, 1992). Today, the carotenoid family is known to include over 600 pigments (Armstrong, 1997) which are mainly synthesised by higher plants, algae and some microorganisms from acetyl-coenzyme A by a series of condensation reactions (Olson, 1989) with global production estimated at $10^{8}$ tons per year (Isler, 1971). The most abundant carotenoid is fucoxanthin from marine algae, followed by lutein, violaxanthin, and neoxanthin from green leaves (Davison et al., 1993).

Carotenoids are known to exist in different geometric forms (cis and trans isomers). These forms may be interconverted by light, thermal energy or chemical reactions (Stahl and Sies, 1993). The vast majority of carotenoids are in the all-trans configuration (Rice-Evans et al., 1997). In recent years much effort has been devoted to the commercial synthesis of carotenoids and as a result six synthetic carotenoids have become commercially available, including $\beta$-apo- $8^{1}$-carotenal, $\beta$-apo- $8^{1}$-carotenoic acid ethyl ester, citranaxanthin, $\beta$-carotene, canthaxanthin and racemic astaxanthin (Pfander, 1992) and total sales of synthetic carotenoids in 1992 were valued at about $\$ 300$ million (Pfander, 1992). Synthetic $\beta$-carotene is almost entirely in the trans isomeric form. Because of their ubiquitous occurrence, important biological functions and health-promoting properties, carotenoids are the subject of interdisciplinary research in many branches of science including poultry science.

Animals and man are not able to synthesise these pigments but are able to make some alterations to the basic chemical structure (Williams et al., 1998 ; Simpson and Chichester, 1981) including oxidation or reduction at the C-4 position of end groups, conversion of $\beta$-end rings into $\varepsilon$-rings and some others (Hudon, 1994). All carotenoids may be derived from the acylic $\mathrm{C}_{40} \mathrm{H}_{56}$ structure having a long central chain of conjugated double bonds (Pfander, 1992) and they can be described by the general formula $\mathrm{C}_{40} \mathrm{H}_{56} \mathrm{O}_{n}$, where $\mathrm{n}$ is $0^{-6}$; hydrocarbons $(\mathrm{n}=0)$ are called carotenes and oxygenated carotenoids $(n=1-6)$ are termed xanthophylls (Castenmiller and West, 1998). Therefore carotenoids are based upon the same $C 40$ isoprenoid skeleton, which is modified by cyclisation, addition, elimination, rearrangement and substitution (RiceEvans et al., 1997). All-trans- $\beta$-carotene is generally considered as the reference compound of its class (Olson, 1992).

In nature, carotenoids are responsible for a variety of bright colours in fall leaves, flowers (narcissus, marigold), fruits (pineapple, citrus fruits, paprika), vegetables (carrots, tomatoes), insects (ladybird), bird plumage (flamingo, cock of rock, ibis, canary) and marine animals (crustaceans, salmon) (Pfander, 1992). These pigments provide different colours from light yellow to dark red and when complexed with 
proteins they can produce green and blue colorations (Ong and Tee, 1992). For example the green pigment of the exoskeleton of the Turkish crayfish is due to the coexistence of blue, green and yellow carotenoproteins (Goodwin, 1992). Furthermore it is necessary to mention that in nature, in addition to carotenoids, there are three other groups of pigments which take part in the coloration of vertebrates and invertebrates : namely, melanins (blacks, greys and browns), porphyrins (egg shell colour) and pteridines (red and yellow colours in fish, amphibians and reptiles) (Hudon, 1994). In this review we will concentrate only on the carotenoids since they exclusively are responsible for egg yolk colour and probably play specific roles in avian embryonic development.

Carotenoids are essential components in oxygenic photosynthetic organisms functioning as antennae in light-harvesting reactions and as quenchers of photosensitized molecules (Davison et al., 1993). Carotenoids protect against the potentially damaging combination of oxygen, light and photosensitising molecules by quenching both the triplet excited states of the photosensitizers and the singlet excited oxygen molecules (Armstrong, 1997). Without carotenoids, photosynthesis and all life in an oxygen atmosphere would be impossible (Britton, 1995). The colour of a given carotenoid is due to the absorption of light (typically $400-500 \mathrm{~nm}$ wavelengths) and is determined by the number of conjugated double bonds within the hydrocarbon backbone (Armstrong, 1997). Carotenoids are associated primarily with the lipid portions of animal tissues and cells, including membranes and cytoplasmic lipid droplets (Bendich and Olson, 1989). As suggested by Olson (1993), carotenoids in bilayer membranes are distributed randomly within the lipid matrix and, in contrast to tocopherols, hydrocarbon carotenoids are not fixed in an orientation perpendicular to the membrane surface. Polar functional groups of the xanthophylls render them more accessible to the aqueous environment (Rice-Evans et al., 1997). Therefore, they are ideally located to trap free radicals which may also form at the membrane hydrophobic/ hydrophilic interface and help to maintain membrane integrity (Woodall et al., 1995). This orientation increases the stability of the membrane (Subczynski et al., 1993). Carotenoids may, therefore, act as modulators of membrane phase transition, fluidity, polarity and permeability, and can thereby influence the general membrane functions and pathology (Socaciu et al., 2000).

The polyene chain of carotenoids is highly unsaturated and, therefore, susceptible to peroxidation and oxidising agents and free radicals rapidly react with carotenoids in vitro. However, in vivo, carotenoids are often present in association with proteins and are therefore protected against electrophilic attack (Rice-Evans et al., 1997).

\section{Carotenoids and vitamin A}

For many years carotenoids have been known as precursors of vitamin A, undergoing the conversion to retinoids in the intestinal wall through central cleavage catalysed by $\beta$-carotene-15, $15^{1}$-dioxigenase (EC 1.13.11.21). This enzyme has been partly purified from the intestinal tissue of several species and has been identified in several other organs (Olson, 1989). Evidence is accumulating that there is an additional 
mechanism, referred to as the eccentric cleavage pathway which involves the formation of $\beta$-apo-carotenoids (Krinsky, 1989 ; Krinsky, 1994). Retinal is formed from carotenoids and it can further undergo reversible reduction to retinol or oxidation to retinoic acid. The provitamin A activities of different carotenoids vary substantially and are shown in Table 1. In the chicken, most of the conversion of provitamin A carotenoids to vitamin A occurs in the intestinal mucosa (Cheng and Deuel, 1950), and a small amount of unchanged $\beta$-carotene escapes conversion and enters the bloodstream (Ganguly et al., 1953) to be deposited in yolk and skin (Williams et al., 1963). Metabolism of $\beta$-carotene to retinal has been shown to also occur in some peripheral tissues, including human adipose tissue, primate lung and kidney (Wang et al., 1991) and bovine corpus luteum (Schweigert et al., 1988).

Data accumulated over the last few years have clearly shown that fewer than $10 \%$ of the 600 types of carotenoid can function as vitamin A precursors in mammals (Rock,

Table 1. Provitamin A activity of some common carotenoids

(Tee, 1992 ; Hencken, 1992 ; Castenmiller and West, 1998)

\begin{tabular}{lc}
\hline \multicolumn{1}{c}{ Carotenoid } & Activity, $\%$ \\
\hline$\beta$-Carotene & 100 \\
9-cis- $\beta$-Carotene & 38 \\
13-cis- $\beta$-Carotene & 53 \\
$\alpha$-carotene & $50-54$ \\
$\alpha$-carotene-5, 6-monoepoxide & 25 \\
3,4-Dehydro- $\beta$-Carotene & 75 \\
$\gamma$-carotene & $42-45$ \\
$\beta$-zeacarotene & $20-53$ \\
$\beta$-Carotene $5^{1}, 6^{1}$-monoepoxide & 21 \\
2,2-Dimethyl- $\beta$-Carotene & 50 \\
3,4-Dehydro- $\beta$-Carotene & 75 \\
Mutachrome, citroxanthin, flavacin & 50 \\
$\beta$-Cryptoxanthin & $50-60$ \\
Isocryptoxanthin & 48 \\
5,6 -Dihydroxy- $\beta$-Carotene & active \\
$\beta$-Apo-2 ${ }^{1}$-carotenal & active \\
4-Keto-carotene & $44-50$ \\
3-Keto- $\beta$-carotene & 52 \\
4-Hydroxy- $\beta$-Carotene & 48 \\
$\beta$-Apo- ${ }^{1}$-carotenal & $66-72$ \\
$\beta$-Apo-12-carotenal & 120 \\
Citranaxanthin & $44-56$ \\
Anhydrolutein & 21 \\
Echinenone & 54 \\
\hline
\end{tabular}


1997). Of these, only about 10 are considered to be nutritionally significant in animals and humans (Davison et al., 1993). $\beta$-carotene, $\alpha$-carotene and $\beta$-cryptoxanthin are the major provitamin A carotenoids in mammals (Olson, 1989). In general, in modern poultry nutrition, synthetic retinyl esters are the main source of vitamin A, with carotenoids in the feed providing only a small part of the total vitamin A requirement. However, carotenoids which are not normally regarded as having provitamin A function can show a provitamin effect under some conditions including vitamin A deficiency (Hencken, 1992). When provitamin A activity was assessed by the epithelial protection test in vitamin A deficient rats, it was shown that in comparison to all-trans $\beta$-carotene, approximately 20 times higher doses of lutein, zeaxanthin or lycopene were required to achieve the same effect on vaginal keratinization (Weiser and Kormann, 1993 ) and this led to relative activities of $4.3 \%$ for zeaxanthin, $5.1 \%$ for lutein and $4.2 \%$ for lycopene. Growth tests with chickens also confirmed the provitamin A activity of zeaxanthin (Weiser and Kormann, 1993). In circumstances of vitamin A deficiency, canthaxanthin probably could also be converted to vitamin A (Hudon, 1994) and this carotenoid may in fact be a substrate for $15,15^{\mathrm{I}}$-carotene-dioxygenase (Canfield et al., 1992). Therefore, the classical division of the carotenoids into provitamin A carotenoids and those without vitamin A activity may not be absolute (Hencken, 1992).

Clearly-defined roles for non-provitamin carotenoids have still to be definitively established (Thurnham and Northrop-Clewes, 1999), but evidence is emerging for several important functions. These include antioxidant activities (Burton, 1989 ; Krinsky, 1989a ; Rice-Evans et al., 1997 ; Edge et al., 1997), the promotion of cell differentiation (Zhang et al., 1991 ; Zhang et al., 1992 ; Rock et al., 1995), regulation

Table 2. Biological functions of carotenoids independent of provitamin A function

\footnotetext{
Antioxidants

Efficient quenchers of singlet oxygen and can directly react with free radicals, participants in vitamin E recycling

Anticarcinogenes

Effective regulators of gap-junction communications between cells

Antimutagenic actions in bacterial systems

Provide protection against mutagens

Immunomodulators

Enhancers of various indices of immune function

Natural colorants

Provide natural coloration to birds, reptiles, amphibians, fish and various invertebrates

Cell membrane stabilizers

Carotenoids are considered as stibilizer of cell membrane fluidity in molluscs Other functions

Specific roles in fertility and embryonic development
} 
of cell proliferation (Krinsky, 1992 ; Bertram and Borthiewicz, 1995) and the enhancement of immune function (Bendich, 1991 ; Hughes, 1999). Biological functions of carotenoids independent on provitamin A activity are summarised in Table 2. These functions of carotenoids are considered to be responsible for the health-promoting properties of carotenoids.

\section{Carotenoid absorption and bioavailability}

Carotenoid absorption and bioavailability have received considerable attention for the last few years (Erdman, 1993 ; van Vilet, 1996 ; Furr and Clark, 1997 ; Castenmiller and West, 1998 ; Parker et al., 1999 ; van het Hof et al., 2000). However, most of these publications were mainly concerned with humans. Analyses of data associated with avian species are presented below.

In general, birds are good oxycarotenoid absorbers although some birds, for example the flamingo, preferentially absorb carotenes (Hudon, 1994). The efficiency of carotenoid assimilation from the feed depends on many factors and absorption in the intestine is a major determinant of this process. In mammals, carotenoid absorption can be divided into four stages : digestion of the food matrix, formation of lipid-mixed micelles, uptake of carotenoids into the intestinal mucosal cells and delivery to the plasma via the lymph system (Williams et al., 1998). In general, details of these stages are very similar to those for vitamin E absorption (Surai, 1999). Since the lymphatic system of the bird is not developed, carotenoids are probably delivered directly to the liver and other tissues by portomicrons, i.e. the lipid-rich lipoproteins released from the intestinal cells into the portal vein.

Feed-derived carotenoids are found in the free alcohol form (maize) or as esterified forms. For example Kuhm et al. (1931) reported that xanthophylls could occur in nature in both free and esterified forms. It was confirmed later that marigold xanthophylls occur primarily as dipalmitic and dimyristic esters (Alam et al., 1968 ; Philip and Berry, 1975). In contrast, carotenoids of corn and alfalfa are found predominately in the free nonesterified form (Bickoff et al., 1954 ; Quackenbush et al., 1961). Therefore carotenoid ester hydrolysis by pancreatic esterases is an important step in their absorption. For example, it has been shown that the dietary lutein diester was hydrolysed mainly to lutein, which was absorbed through the intestinal wall into the blood stream and, in the serum, about $96 \%$ of the total lutein occurred as the free alcohol and the remainder was in the form of the monoester (Tyczkowski and Hamilton, 1986). As a result, hens fed lutein diester accumulated lutein in their yolks (Philip et al., 1976). When hens were fed zeaxanthin diester, the egg yolk contained only free zeaxanthin (Kuhn and Brockman, 1932). It was possible to improve egg yolk pigmentation by prior saponification of marigold meal xanthophyll (Coon and Couch, 1976). Furthermore, in broilers free lutein is absorbed almost two fold faster compared to lutein diester (Tyczkowski and Hamilton, 1986). In contrast, in humans lutein diesters showed a trend toward greater bioavailability compared to free lutein (Herbst et al., 1997). It is interesting to note that, in the chicken, the contents of the jejunum and large intestine contained a mixture of lutein diester, lutein monoester, and lutein, 
but in the serum lutein was found mainly $(90 \%)$ in the nonesterified form (Tyczkowski and Hamilton, 1986). Similarly, in the liver lutein monoester and diester comprise about 20 and $2 \%$ of total lutein respectively (Hamilton. 1992). In contrast, in the toe web about half of the total lutein occurred as the diester and the remainder occurred as about equal amounts of free lutein and lutein monoester (Tyczkowski and Hamilton, 1986).

Different experimental models were developed to evaluate the biological availability of carotenoids from various feed sources. Using a chicken model and $\beta$-apo- $8^{\mathrm{I}}$ -carotenoic acid ethyl ester (Apo-EE) as a reference, it was shown that the relative biological availability of xanthophyll from various sources to be (\%) : Apo-EE 100, corn gluten meal 64.2 (47.7-89.1), dehydrated alfalfa 45.9 (34.6-65.4), marigold meal 29.1, marigold extracts 62.9 and coastal Bermugrass 22.2 (18.8-27.9) (Middendorf $e t$ $a l ., 1980)$. In this experiment, statistically significant differences among samples within and among generic sources were obtained. Furthermore, xanthophyll (lutein + zeaxanthin) concentrations in different feed vary substantially $(\mathrm{mg} / \mathrm{kg}):$ lucerne meal (40-260), grass meal (140-500), yellow maize (8-40), plate maize (10-50) and maize gluten meal (60-360) (Belyavin and Marangos, 1989). The main dietary factors determining carotenoid bioavailability have been discussed in a recent review (van het Hof et al., 2000).

The main dietary sources of carotenoids in poultry nutrition in Europe are maize, maize products, lucerne, alfalfa meal and commercial concentrated forms including marigold and paprika (Nys, 2000). Most of the mentioned feedstuffs provide mainly lutein and zeaxanthin plus $\beta$-carotene (alfalfa meal) and $\beta$-cryptoxanthin (maize and maize gluten). Our data indicate that a major difference between the American maize-based diet for breeders and the European wheat-barley based diet is in the level of carotenoids (lutein + zeaxanthin), which is more than twice higher in the maizebased diet (Surai and Sparks, 2000). This difference is due to a low carotenoid content of wheat and barley although both feeds contain lutein and zeaxanthin as major carotenoids.

After ingestion of feed, carotenoids are released from the matrix by digestive enzymes. The liberated carotenoid compounds together with other feed lipids are emulsified in the presence of bile salts to form oil droplets. Indeed, it may well be that carotenoids can spontaneously transfer from lipid droplets to mixed micelles. Because of their large size, the droplets are not able to gain proximity to the absorptive surfaces of the small intestine for carotenoid transfer to enterocytes (Combs, 1996). Instead, as a result of lipase action, the droplets are degraded to form mixed micelles. The hydrophobic cores of the micelles contain nonpolar, nonamphiphilic lipids, such as cholesterol and oxycarotenoids, which partition between the oil and micellar phases.

It is evident that carotenoid absorption from the intestinal tract is associated with the same intraluminal, membrane and intracellular events as have been described for dietary lipids (Krogdahl, 1985) although some specific features relating to the site of absorption of various carotenoids in birds have been described (Tyczkowski and Hamilton, 1986b). This process includes emulsification, solubilization, diffusion across 
the unstirred water layer, permeation through the membrane of the enterocytes, incorporation into lipoprotein particles and release into the circulation via lymphatic pathways in mammals (Cohn, 1997), or the portal system in birds. It is noteworthy that carotenoid absorption is a very delicate and sensitive process and it is likely that an impairment of any of these stages will decrease carotenoid assimilation from the diet. On the other hand, in some cases a promotion of lipid solubilization or micelle formation might increase carotenoid absorption and assimilation. For example, simultaneous dietary supplementation of sodium cholate and $\beta$-carotene markedly enhanced the accumulation of $\beta$-carotene in mice (Umegaki et al., 1995).

In birds, lipid digestion starts in the gizzard where bile salts and pancreatic lipases are responsible for about $30 \%$ of dietary triglyceride hydrolysis (Sklan et al., 1978). Emulsification of dietary fat is accelerated greatly as the chyme moves into the small intestine and is mixed with bile and pancreatic secretion. The jejunum is the major site of lipid absorption in birds, although some absorption occurs in the ileum (Hurwitz et $a l ., 1973)$. It has been shown that lutein is absorbed in the duodenum and jejunum (Hamilton, 1992) but absorption of zeacarotene takes place mainly in the ileum (Tyczkowski and Hamilton, 1986). Results of the experiments of Tyczkowsky and Hamilton suggest that carotenoid absorption takes place by unsaturable, passive diffusion down a concentration gradient similar to other nonpolar lipids (Hamilton, 1992), although some stereospecificity for R-carotenoids has been shown (Hencken, 1992 ; Schiedt et al., 1985). It thus appears that carotenoids are absorbed in the free alcohol form by passive diffusion across the brush border membranes of the intestinal mucosal epithelium (Cohn, 1997) and the process is thought to be concentration dependent (Bieri and Farell, 1976).

Bile salts and phospholipids take part in the emulsification of dietary triglycerides and other fat soluble nutrients, including carotenoids. Pancreatic lipase acts on the triglycerides at the water-lipid interface. Free fatty acids and monoglycerides formed during hydrolysis of triglycerides, in the presence of bile salts, spontaneously form very small particles, called mixed micelles. Thus, solubilization of water-insoluble materials such as carotenoids is a critical step in their digestion and absorption. Because of the very small size of mixed micelles, they are dispersed in the aqueous environment of the intestinal lumen and can diffuse into the glycoprotein layer surrounding the microvilli or brush border of mucosal cells, where they come into contact with the cell membranes (Tee, 1992). The micelles migrate to and merge with the membranes of intestinal epithelial cells and so the carotenoids within the lipid micelles come in contact with the intestine epithelial cell membranes and their transport to the plasma membrane and/or cytosol of the cell takes place in concert with the transport of fatty acids, monoglycerides and other lipids (Erdman et al., 1993). It is known that the passage of lipids through the brush border membrane is passive, and absorption rates depend on the fatty acid chain length and degree of saturation (Krogdahl, 1985).

Furr and Clark (1997) suggested that the mixed micelles penetrate the unstirred water layer, a series of water lamellae adjacent to the microvillus surface. The unstirred water layer and the microvillus membrane are two barriers through which carotenoids 
must pass. In general movement through the unstirred water layer is a rate limiting factor for lipid absorption (Westergaard and Dietschy, 1976). It appears reasonable to assume, therefore, that the same is true for carotenoid absorption.

Thus it is becoming increasingly evident that the micelles formed from dietary lipids serve as a delivery system for carotenoids to reach the absorptive surface of the gut. The micelles facilitate fat absorption by providing a high concentration of lipids in the unstirred water layer adjacent to the mucosal cells and disruption of the micelles is necessary before absorption takes place (Krogdahl, 1985). The feed matrix is thought to be an important determinant for the absorption of carotenoids and therefore carotenoid absorption varies substantially among different foods and their bioavailabilities can be improved by disruption of the food matrix (van het Hof et al., 1999 a). The amount and type of feed determine bile secretion, while bile salts and fat determine micelle formation (van Vliet, 1996). The $\mathrm{pH}$ in the intestinal lumen may also affect absorption via an effect on the surface charges of both the micellar particles and the luminal cell membrane, with less diffusion resistance at lower $\mathrm{pH}$ values (Hollander, 1981).

The efficiency of dispersion of carotenoids is known to be affected by the presence or absence of other components in the diet, as well as by the general nutritional status of the animal. For example, soluble protein and peptides derived from feed are able to assist in the dispersion of the carotenoids. Furthermore, fat in the diet provides the vehicle for transporting the carotenoids from the proventriculus and gizzard into the intestinal lumen and is the source of some of the digestion products which take part in micelle formation. In general, the amount and quality of dietary fat have major influences on bile secretion and micelle formation and therefore on the efficiency of carotenoid absorption in small intestine. Recent findings indicate that optimal uptake of vitamin $\mathrm{E}$ and $\alpha$ - and $\beta$-carotene requires a limited amount of fat whereas the amount of fat required for optimal intestinal uptake of lutein esters is much higher (Roodenburg et al., 2000). In this respect, the studies of Hollander (1981) show that the presence of fatty acids, of varying chain length and the degree of saturation, substantially affect absorption rate. Short chain saturated fatty acids and long-chain unsaturated fatty acids improved lutein absorption in chicken (Hamilton, 1992). Natural antioxidants can also improve carotenoid assimilation. For example, an increased accumulation of liver xanthophylls in chicks was observed as a result of feeding ethoxyquin (Bartov and Bornstaein, 1972). However, the carotenoid concentration achieved in the yolk was unaffected by dietary (-tocopherol (Frigg et al., 1992). It has been summarised that 9 major factors determine carotenoid bioavailability : species of carotenoids, molecular linkage, amount of carotenoids consumed in a meal, matrix in which the carotenoid is incorporated, effectors of absorption and bioconversion, nutrient status of the host, genetic factors, host-related factors and nutrient interactions (Castenmiller and West, 1998). All these factors are relevant to birds. Some of the effectors of carotenoid absorption are shown in Table 3. In general, carotenoid interactions could play a substantial role in efficiency of carotenoid assimilation from the feed.

Animals and humans appear to absorb various carotenoids in a relatively non- 
Table 3. Effectors of carotenoid absorption and assimilation

(Rock, 1997 ; Hudon, 1994 ; Nys, 2000)

\section{Dietary factors}

Fat increases absorption and stimulate bile flow from the gall bladder

Soluble fibre (e.g. pectin) interferes with uptake

Aflatoxin and ochratoxin depress carotenoid absorption

Vitamin A status (due to effect on intestinal conversion)

Protein level and status

Iron and zinc status

Dosage of carotenoid administered (reduced efficiency at higher levels)

Competitive interactions between carotenoids

\section{Food form}

Location in plant tissues (e.g. plant cell chloropla sts may be less bioavailable than chloroplasts)

Mild heat treatment increases bioavailability

Reduced particle size (i.e., blenderizing) improves extractability

\section{Biochemical and metabolic factors}

Isomeric form, but effect (positive versus negative) varies with carotenoid

Large interindividual variability, likely due to metabolic or absorption polymorphism

Sex, age, hormonal status and season effect carotenoid metabolism

Genetic make-up influence carotenoid metabolism (colour of Northern Flicker has a genetic, not a dietary basis).

\section{Subject characteristics}

Intestinal parasites associated with reduced absorption

Coccidiosis, Newcastle disease or chronic respiratory disease decrease carotenoid assimilation

Malabsorption syndromes (especially involving fat) reduce absorption

Liver or kidney disease

Increased gastric $\mathrm{pH}$ associated with suppressed blood response

Environmental factors (captive vs wild)

specific fashion, but absorption kinetics and plasma transport seem to differ among carotenoids, possibly because of differences in polarity. Although interactions among carotenoids do exist, their importance and the mechanisms involved are still unclear (van Vliet, 1996). There is some biodiscrimination between different carotenoids and their stereoisomers during absorption. There are also variations in availability of individual carotenoids. For example, the relative bioavailability of lutein from vegetables is 5 times higher than that of $\beta$-carotene (van het Hof et al., 1999). It is interesting that enzymatic disruption of the matrix (cell wall structure) enhanced the bioavailability of $\beta$-carotene from whole leaf and minced spinach, but had no effect on lutein bioavailability (Castenmiller et al., 1999). In addition, in the human, in the presence of high amounts of $\beta$-carotene, there is a preferential uptake of the xanthophylls lutein and zeaxanthin as compared to all-trans $\beta$-carotene from the intestinal 
lumen into chylomicrons (Gartner et al., 1996).

On the other hand, recent results indicate an inhibitory effect of lutein on $\beta$-carotene absorption, but apparently not on $\beta$-carotene cleavage. In a comparative study with two $\beta$-carotene/lutein ratios ( $2: 1$ and $1: 2$, respectively), this inhibitory effect of lutein was found to be most marked when lutein was the predominant carotenoid (van den Berg, 1998). In contrast, ingestion by men of a combined dose of $\beta$-carotene and lycopene does not affect the absorption of $\beta$-carotene but improves that of lycopene (Johnson et al., 1997). Dietary consumption of canthaxanthin has a specific antagonistic effect on the bioavailability of a $\beta$-carotene in ferrets (White $e$ t al., 1993). However, in the human, a combined pharmacologic dose of $\beta$-carotene and canthaxanthin reduces the bioavailability of the canthaxanthin dose (White et al., 1994). It has been suggested that canthaxanthin at high doses competes with $\beta$-carotene for intestinal absorption and inhibits the conversion of $\beta$-carotene to vitamin A (Grolier et al., 1997).

The average efficiency of canthaxanthin absorption in rats was $16 \%$ while the efficiency of lycopene absorption averaged only $6 \%$. Efficiency of carotenoid absorption was not related to the concentration infused and the carotenoids did not significantly affect each other's absorption (Clark et al., 1998). In the chicken, carotenoid absorption and accumulation is also low. In broilers, 94\% of astaxanthin and about $83 \%$ of zeaxanthin supplied by the diet were excreted and only $0.4 \%$ of the astaxanthin and $1.7 \%$ of the zeaxanthin were deposited in the skin (Hencken, 1992). Cryptoxanthin in particular is very poorly absorbed in birds (Quackenbush, 1970 ; Tyczkowski and Hamilton, 1986 b). In laying hens, carotenoid deposition in egg yolk is also comparatively low with canthaxanthin being deposited at 30-45\% efficiency, zeaxanthin 25\% and astaxanthin 14\% (Hencken, 1992) and carotenoid excretion was about $70 \%$ for astaxanthin and zeaxanthin and $45-50 \%$ for canthaxanthin. Earlier it had been shown that $43 \%$ (Nakaue et al., 1966) or 56\% (Marusich and Bauernfeind, 1981 ) of the ingested zeaxanthin was deposited in egg yolks. In the same experiment, the levels of deposition of cryptoxanthin, lutein and violaxanthin were 21,9 and $0 \%$ respectively (Nakaue et al., 1966). Astaxanthin transfer from the yeast Phaffia rhodozyma, added to the diet of the quail, to the egg yolk comprised only $4 \%$ of the ingested carotenoid ; from marigold extract carotenoid transfer to the egg yolk was even lower (3\%) (Johnson et al., 1980). About 16\% of capsanthin was transferred from the diet (as a saponified oleoresin) into the egg yolk (Hamilton et al., 1990) but when crystalline capsanthin was used only $6.2 \%$ of this carotenoid was transferred to the egg yolk (Marusich et al., 1960). In accordance with other observations the efficiency of the deposition of capsanthin from various capsicum products varied from 1 to $6 \%$ (see Hamilton et al., 1990).

Therefore only a small to moderate percentage of the carotenoid ingested with feed will be taken up by the intestinal cells. For example, in humans, $\beta$-carotene absorption from a meal ranges from 3\% up to 50\% (Erdman et al., 1993). In chickens, when the mucosal cells are sloughed off into the lumen of the gastrointestinal tract, carotenoids which were not incorporated into portomicrons are lost (Williams et al., 1998). 
In poultry, lipoproteins synthesised in the intestinal wall are drained from the intestines by portal blood. Thus it is widely thought that in the absence of a developed intestinal lymphatic system in birds, absorbed lipids enter the portal system as large lipoproteins (called portomicrons) with a diameter of about $150 \mathrm{~nm}$ (Annison, 1983, Walzem, 1996). They consist of triglycerides, free and esterified cholesterol, phospholipids and apoproteins, and fat-soluble vitamins including carotenoids. Very little is known about the cellular events that regulate or mediate the incorporation of carotenoids into portomicrons. This process could be facilitated by cytosolic binding proteins but these have not been reported in the intestinal mucosa.

Thus, carotenoids together with other lipids are transported as portomicrons directly via the portal system to the liver prior to entry into the general circulation. In contrast, in mammals, chylomicrons are delivered into the plasma via the lymphatics and circulate through extrahepatic tissues before the passing through the liver. In the capillaries of certain extrahepatic tissues, chylomicrons are hydrolysed by lipoprotein lipase (LPL), with subsequent transfer of some carotenoids to the peripheral tissues and to other lipoproteins. In birds, portomicrons partly undergo some transformation in the liver, but, probably, they are largely released into the circulation unchanged or with minor changes. During their transport in the circulation, portomicrons also undergo catabolism by LPL. This enzyme is synthesised in several chicken tissues, but the largest amounts are associated with skeletal muscle and adipose tissue (Stevens, 1996). LPL is secreted into the capillaries where it is bound on the luminal side of the endothelial cells. Lipoproteins are substrates for endothelial bound LPL which catalyses intravascular triglyceride hydrolysis.

During portomicron catabolism by LPL, the size of the portomicron triglyceride core is reduced and excess surface is created. This excess surface is transferred to HDL (Traber, 1996) and a portion of the carotenoid content is also transferred to HDL. Because HDL readily transfers vitamin $\mathrm{E}$ and probably carotenoids to other lipoproteins (Traber et al., 1992), carotenoids are distributed between all of the circulating lipoproteins. Portomicron remnants are cleared from circulation by the liver and in this way carotenoids are delivered to this organ. The factors controlling carotenoid uptake by various avian tissues and their transfer to egg yolk are not known and this subject warrants further investigation. For example recently it has been shown that androgens modulate hepatic lycopene metabolism (Boileau et al., 2000).

\section{Carotenoids in avian plasma and egg yolk}

The carotenoid concentration in avian plasma has received little attention and varies significantly depending on the dietary provision. It has been shown that species with carotenoid-dependent coloration display higher concentrations of plasma carotenoids compared with species with no external display of carotenoids (Trams, 1969 ; Hill, 1995). There are two possible explanations for such differences (Hill, 1995). First of all, the dietary intake of carotenoids differs significantly among species and species-specific differences in carotenoid assimilation could also exist.

Data on poultry were obtained mainly with chickens of different ages and fed on 
diets with various carotenoid concentrations. For example, in laying hens the plasma carotenoid concentration was $0.7 \mu \mathrm{g} / \mathrm{m} l$ when fed on a standard commercial diet and increased up to $3.0 \mu \mathrm{g} / \mathrm{m} l$ after carotenoid dietary supplementation (Surai et al., 1999). After a high level of dietary supplementation with lutein, the concentration of this pigment in the serum of the laying hen was $19.8 \mu \mathrm{g} / \mathrm{ml}$ (Haq et al., 1995) and in the serum of broilers it was $25.1 \mu \mathrm{g} / \mathrm{ml}$ (Tyczkowski et al., 1986). In broilers at 46 days of age fed on a commercial wheat-soybean meal ration, the serum xanthophyll concentration was $1.3 \mu \mathrm{g} / \mathrm{ml}$ and increased up to $4.2 \mu \mathrm{g} / \mathrm{ml} 24$ hours after corn gluten meal or marigold meal intubation (Middendorf et al., 1980 a). In contrast, in a low carotenoid diet control group, carotenoids were not detectable in the serum of laying hens (Haq et al., 1995). In day old chicks hatched from eggs laid by hens on a standard commercial diet, the carotenoid concentration in plasma was $3.1 \mu \mathrm{g} / \mathrm{m} l$ and this increased to $9.4 \mu \mathrm{g} /$ $\mathrm{m} l$ in chicks hatched from eggs enriched with carotenoids (Surai and Speake, 1998). The carotenoid concentration in the serum of 3-week old and 5-week old chicks hatched from eggs enriched with lutein was 2.7 and $1.1 \mu \mathrm{g} / \mathrm{m} l$ respectively (Haq et al., 1995). In 37-day old chickens fed on a commercial diet, the plasma carotenoid concentration was $2.6 \mu \mathrm{g} / \mathrm{ml}$, but after supplementation with $\beta$-carotene, zeaxanthin or canthaxanthin $(100 \mathrm{mg} / \mathrm{kg}$ diet in each case), it increased to $3.3,15.5$ and $7.1 \mu \mathrm{g} / \mathrm{ml}$ respectively (Woodall et al., 1996).

Much higher carotenoid concentrations can be found in the plasma of wild birds. For example, in 356 wild birds from 26 species, the carotenoid concentration in plasma varied from 0.4 up to $74.2 \mu \mathrm{g} / \mathrm{ml}$ (average $9.4 \mu \mathrm{g} / \mathrm{ml}$ ) (Tella et al., 1998). In white storks, the plasma carotenoid concentration was $2.2 \mu \mathrm{g} / \mathrm{ml}$ and this increased to 11.1 $\mu \mathrm{g} / \mathrm{ml}$ in the same species when fed on crayfish (Negro et al., 2000 a). Plasma concentration of carotenoids in wild American Kestrels in captivity varied from approximately $4 \mu \mathrm{g} / \mathrm{m} l$ up to $87 \mu \mathrm{g} / \mathrm{m} l$ depending on the season, sex, age of the birds (Negro et al., 1998) and, in wild shrikes, the carotenoid concentration in plasma varied from approximately $10 \mathrm{up}$ to $20 \mu \mathrm{g} / \mathrm{ml}$ (Bortolotti et al., 1996). In the American flamingo, the carotenoid concentration in plasma was $35 \mu \mathrm{g} / \mathrm{ml}$ (Fox et al., 1969 ; Hill, 1999), in the roseate spoonbill 8.0-14.0 $\mu \mathrm{g} / \mathrm{ml}$ (Fox et al., 1965 ; Hill, 1999), and in the red-legged partridge it was $4.0-6.5 \mu \mathrm{g} / \mathrm{m} l$ (reviewed by Hill, 1999). In the male barn swallow, lutein (the main carotenoid) concentration in plasma was $2.4-3.0 \mu \mathrm{g} / \mathrm{m} l$ (Saino et al., 1999).

Slifka et al. (1999) studied carotenoid concentrations in the serum of various avian species in Brookfield Zoo (Chicago) and they were as follows $(\mathrm{mg} / \mathrm{ml}):$ american flamingo 9.7-19.5, greater flamingo 16.2-24.9, mandarin duck 0.8-3.6 ; grey gull 0.652.9 ; scarlet ibis $1.2-1.5$; inca tern $0.4-0.9$; wood duck 0.54 ; hybrid teal 0.49 ; Hadada ibis 0.40 ; whistling duck $0.3-0.5$; brown pelican $0.3-0.5$; sacred ibis $0.1-0.3$; Humboldt penguin 0.02-0.08 and Brasilian teal 0.04.

In early studies conducted by Palmer (1915) and Palmer and Kempster (1919), it was shown that xanthophylls in body tissues and egg yolks were a reflection of their dietary composition. By feeding isolated xanthophylls to chickens, Ganguly et al. (1953) also found that the types of carotenoids found in blood and tissues reflect those 
in the feed. In general, the profile of carotenoids deposited in the skin closely resemble those of the diet (Livingston et al., 1969). On the other hand, Smith and Perdue (1966) reported that the profile of xanthophills in broiler skin differed significantly from those in the diet. Dua et al. (1967) showed highly significant correlations between the profiles of xanthophylls in the diet, plasma and skin. Furthermore, violaxanthin is not transferred from the feed to egg yolk (Marusich et al., 1960 ; Nakaue et al., 1966) and to the skin (Kuzmicky et al., 1969). Neoxanthin also possessed low pigmenting efficiency for the skin (Kuzmicky et al., 1969). Recently it has been shown that in plasma, skin and fat of crayfish-eating white storks, the major carotenoid was astaxanthin, reflecting its high concentration in crayfish (Negro et al., $2000 \mathrm{a}$ ). In free living adult gulls, lutein, zeaxanthin, canthaxanthin, echinenone and $\beta$-carotene were identified in the liver and peripheral tissues (Surai et al., 2000 b). It is, however, not clear if all those carotenoids originated from the diet or some interconversions of carotenoids took place. During the rapid growth of the ova, xanthophylls are deposited in the egg yolk in a dose-dependent manner (Hinton et al., 1974).

The concentration of carotenoids in egg yolk is a reflection of their dietary provision. In the egg yolk of Rhode Island Red chickens fed on a commercial wheat-barley based diet, the carotenoid concentration was 10.8-12.6 $\mu \mathrm{g} / \mathrm{g}$ (Surai et al., $1998 \mathrm{a})$. Similar concentration of carotenoids $(13.3 \mu \mathrm{g} / \mathrm{g})$ was reported in the egg yolk of laying hens fed on a wheat-barley-soya-based diet (Surai and Speake, 1998). In contrast, much lower yolk carotenoid concentrations $(1.4 \mu \mathrm{g} / \mathrm{g})$ were reported when chicken were fed on a wheat-barley diet and this decreased further down to $0.2-0.4 \mu \mathrm{g} /$ $\mathrm{g}$ when laying hens were fed a specially designed low carotenoid diet (Strand et al., 1998). Inclusion of seaweed in the diet substantially increased the carotenoid concentration in egg yolk (to $4.8-8.0 \mu \mathrm{g} / \mathrm{g}$ ). In another experiment, in which hens were placed for 3 weeks on a low-carotenoid diet to reduce the yolk's carotenoid concentration to $1.9 \mu \mathrm{g} / \mathrm{g}$ (Hamilton and Parkhurst, 1990), subsequent feeding with saponified oleoresin of marigold (to supply $70 \mathrm{mg}$ lutein per $\mathrm{kg}$ of the diet), increased the carotenoid concentration in the egg yolk to $45.4 \mu \mathrm{g} / \mathrm{g}$ and simultaneous inclusion in the diet of cottonseed oil further increased the yolk carotenoid concentration to $80.9 \mu \mathrm{g} / \mathrm{g}$ (Hamilton and Parkhurst, 1990). A white corn-soybean meal diet containing $0.27 \mathrm{mg}$ carotenoids $/ \mathrm{kg}$ of diet provided carotenoids in the egg yolk at the level of $0.2 \mu \mathrm{g} / \mathrm{g}$ and additional inclusion of carotenoids into the diet at the level of $16 \mathrm{mg} / \mathrm{kg}$ increased carotenoid concentration only to $1-2 \mu \mathrm{g} / \mathrm{g}$ (Hamilton et al., 1990).

For chickens fed on a maize based diet, the carotenoid concentration recorded in the egg yolk varied from 24 to $30 \mu \mathrm{g} / \mathrm{g}$ (Surai et al., 1996 ; 1998 ; Handelman et al., 1999 ; Schaeffer et al., 1988). A corn-gluten based diet provided xanthophylls at a level of $20 \mathrm{mg} / \mathrm{kg}$ of feed and resulted in a carotenoid (xanthophyll) concentration in the egg yolk of $35 \mu \mathrm{g} / \mathrm{g}$ (Fletcher, 1980). In our recent study (Surai and Sparks, 2000), it was shown that when a maize-based diet was fed to laying hens, the carotenoid concentration achieved in the egg yolk was $32 \mu \mathrm{g} / \mathrm{g}$ compared to $15.2 \mu \mathrm{g} / \mathrm{g}$ in the egg yolk from hens fed on a wheat-barley diet. Chickens hatched from those eggs had carotenoid concentrations in their plasma of 10.7 and $6.0 \mu \mathrm{g} / \mathrm{m} l$ respectively. 
It is interesting that turkey, duck and goose eggs obtained from females fed on a maize-based diet contained much less carotenoids $(19.6,17.3$ and $14.6 \mu \mathrm{g} / \mathrm{g}$ respectively) than observed for chicken's eggs, reflecting species specificity in carotenoid absorption and transfer to egg yolk (Surai et al., 1998). Supplementation of the diet of laying hens with a high level of lutein caused a substantial accumulation of this carotenoid in the egg (100-120 $\mathrm{g} / \mathrm{g}$; Surai et al., $2000 \mathrm{a})$.

When housed geese were fed on a wheat-barley diet, the carotenoid concentration in the egg yolk was as low as $2.1 \mu \mathrm{g} / \mathrm{g}$ (Speake et al., 1999 a) and the egg yolk was almost colourless. It is interesting to note that free range geese with an access to grazing had a much higher carotenoid concentration in the egg yolk $(37.3 \mu \mathrm{g} / \mathrm{g})$ and feral Canada geese also displayed high carotenoid concentration in the egg yolk $(22.1 \mu \mathrm{g} / \mathrm{g})$ (Speake et al., 1999 a).

Eggs of the lesser black-backed gull collected in the wild were characterised by comparatively high carotenoid concentrations $(56.8 \mu \mathrm{g} / \mathrm{g}$ ) (Royle et al., 1999). In contrast, the yolk of eggs of the emperor penguin collected in Antarctica was quite pale and characterised by low carotenoid concentrations $(2.3-3.2 \mu \mathrm{g} / \mathrm{g}$ ) (Speake et al., 1999). The carotenoid concentrations in the egg yolk of wild gannet, skua, pelican and cormorant were respectively $(\mu \mathrm{g} / \mathrm{g}): 17.7,12.7,150.9$ and 115.7 (Surai et al., 2000). In moorhen and coot egg carotenoid concentration was 47.5 and $131.0 \mu \mathrm{g} / \mathrm{g}$ respectively (Surai et al., $2000 \mathrm{c}$ ). Therefore pelican and coot eggs were characterised by the highest carotenoid concentration registered in avian species so far.

Carotenoids are also present in the yolk of some, but not all, reptiles. For example, in the egg yolk of the omnivorous Murray short-necked turtle, the carotenoid concentration was $9.8 \mu \mathrm{g} / \mathrm{g}$ (Thompson et al., 1999 a) and the egg yolk of the herbivorous Hermann's tortoise reared in captivity contained $14.6 \mu \mathrm{g}$ carotenoid/g (Speake et al., 2000). In contrast, no carotenoids were detected in the eggs of two species of insectivorous lizards (Thompson et al., $1999 \mathrm{~b}, \mathrm{c}$ ).

Although it is well accepted that the carotenoid composition of egg yolk reflects their composition in the feed, many species have the capacity to chemically modify and selectively deposit the pigments (Brush, 1990). To various extents, $\beta, \beta$-carotene, $\beta$-cryptoxanthin, canthaxanthin, lutein $A$, zeaxanthin, $\left(3 \mathrm{R}, 6^{1} \mathrm{R}\right)$-3-hydroxy- $\beta-\varepsilon$ caroten-3 $3^{1}$-one, $\quad\left(3 \mathrm{R}, 6^{1} \mathrm{~S}\right)$-3-hydroxy- $\beta$-caroten- $3^{1}$-one, $\quad\left(6 \mathrm{~S}, 6^{1} \mathrm{~S}\right)-\varepsilon, \varepsilon$-caroten- $3,3^{1}$ -dione, and ( $6 \mathrm{R}, 6^{1} \mathrm{~S}$; meso)- $\varepsilon, \varepsilon$-caroten-3, $3^{1}$-dione, (3R, $\left.6 \mathrm{R}, 6^{1} \mathrm{R}\right)$-3-hydroxy- $\varepsilon$, $\varepsilon$-caroten-, $3^{1}$-one and $\left(3 \mathrm{R}, 6 \mathrm{R}, 6^{1} \mathrm{~S}\right)$-3-hydroxy- $\varepsilon, \varepsilon$-caroten-, $3^{1}$-one have been reported to be present in the egg yolk and liver of the chicken (Matsuno, 1989). $4^{1}$ -Hydroxy-echinenone and isozeaxanthin were also found in egg yolk after dietary canthaxanthin supplementation (Schiedt, 1989). Also capsanthin, neoxanthin, flavoxanthin and lutein 5,6-epoxide if present in the diet are all laid down in the egg (Goodwin, 1984). When seaweeds containing high concentrations of violaxanthin and fucoxanthin were fed to layers, the egg yolk contained flavoxanthinoids, auroxanthinoids and fucoxanthinoids in addition to lutein and zeaxanthin (Jensen, 1963). It has been suggested that over $90 \%$ of xanthophylls in the egg are esterified (Goodwin, 1984) but our recent analyses using several different HPLC systems (Surai, un- 
published) clearly showed that, in the egg, the esterified forms of carotenoids comprised a very low $(<1 \%)$ proportion of the total carotenoids. Astaxanthin and echinenone were reported in the egg yolk of various avian species (Goodwin, 1984). We also found echinenone in eggs of the lesser black-backed (Surai, unpublished). In their review, Marusich and Bauernfeind (1981) also mentioned the presence in egg yolk of esterified xanthophylls, flavoxanthin, $\alpha$-carotene, $\varepsilon$-carotene, lycopene and violaxanthin. The effectors of carotenoid accumulation in the egg are shown in Table 4.

Thus, as a result of numerous experiments with various carotenoid sources, it has been concluded that the colour of yolk results from the relatively nonspecific deposition of oxycarotenoids (Marusich and Bauernfeind, 1981). One requirement for deposition is that the oxycarotenoid possesses functional groups containing oxygen, such as hydroxyl, keto, or ester groups, which impart moderately polar characteristics. Since

Table 4. The effectors of carotenoid accumulation in the egg (Goodwin, 1984 ; Marusich and Bauernfeid, 1981)

\begin{tabular}{|c|c|}
\hline Effector & Effect \\
\hline \multicolumn{2}{|l|}{ Negative effects } \\
\hline Glutamate, lysine or nitrate & Reduces carotenoid levels in broilers \\
\hline $\begin{array}{l}\text { Infections : Eimeria spp, } \\
\text { Coccidiosis and chronic } \\
\text { disease }\end{array}$ & Reduce carotenoid blood level \\
\hline Aflatoxin or ochratoxin A & $\begin{array}{l}\text { Reduces blood levels of carotenoids and causes the } \\
\text { appearance of pale carcasses }\end{array}$ \\
\hline Tetramycin & $\begin{array}{l}\text { Inhibits the conversion of carotenoids into vitamin } \\
\text { A }\end{array}$ \\
\hline High temperature & A drop in egg yolk pigmentation \\
\hline High levels of vitamin A & Decreases carotenoid concentration in the egg yolk \\
\hline Fish oil and fish meal & Decrease egg yolk pigmentation \\
\hline \multicolumn{2}{|l|}{ Positive effects } \\
\hline Presence of zinc in the diet & $\begin{array}{l}\text { Improves the absorption of food carotenoids and } \\
\text { results in higher levels in eggs }\end{array}$ \\
\hline Selenium & $\begin{array}{l}\text { Improves the conversion of beta-carotene into } \\
\text { vitamin A }\end{array}$ \\
\hline Vitamin $\mathrm{E}$ and other antioxidants & Improve yolk pigmentation \\
\hline Vitamin $\mathrm{B}_{12}$ & Improves egg yolk pigmentation \\
\hline Streptoxanthin & $\begin{array}{l}\text { Increases carotenoid absorption and skin color- } \\
\text { ation }\end{array}$ \\
\hline
\end{tabular}

Table 5. The distribution of major carotenoids in plasma lipoproteins of newly hatched chick, \% (Surai and Speake, unpublished)

\begin{tabular}{lcccc}
\hline \hline Carotenoid & VLDL & IDL & LDL & HDL \\
\hline Lutein & 2.72 & 1.16 & 5.95 & 90.82 \\
Zeaxanthin & 2.61 & 0.98 & 5.62 & 90.79 \\
\hline
\end{tabular}


the hydrocarbon carotenoids, such as $(\beta$-carotene, do not possess such functional groups and are not deposited in the yolk of the chicken in any significant quantities (Marusich and Bauernfeind, 1981), it was also suggested that, in poultry, $\beta$-carotene is almost completely converted into vitamin $\mathrm{A}$ or is otherwise metabolised and therefore does not contribute to the pigmentation of egg yolk (Hencken, 1992). For example, when very large amounts of $\beta$-carotene were fed to laying hens at either 50 or $400 \mathrm{mg}$ / $\mathrm{kg}$ feed, its concentration in the egg yolk was only 1.8 and $4.8 \mu \mathrm{g} / \mathrm{g}$ respectively, representing a very inefficient transfer; eggs from unsupplemented hens contained $\beta$-carotene at only $0.14 \mu \mathrm{g} / \mathrm{g}$ (Jiang et al., 1994). The suggestion that $\beta$-carotene is not normally a component of yolk was automatically assumed to apply to all avian species. However, our recent results indicate that $\beta$-carotene is presents at high concentrations in the egg yolk of several avian species in the wild. For example, in gull's eggs, $\beta$-carotene comprises more than $30 \%$ of total carotenoids (Royle et al., 1999) and it also accumulates in the liver of adult gulls (Surai et al., 2000 b). High proportions of $\beta$-carotene were also found in moorhen and coot eggs (Surai et al., $2000 \mathrm{c}$ ).

As one can expect, the profile of carotenoids present in the yolk of the newly laid egg depends to a large extent on the type of carotenoids present in the diet of the parent hen (Surai and Speake, 1998). However, other factors in the laying hen, such as the efficiency of absorption of the various carotenoids from the intestine and the extent to which certain carotenoids are converted to vitamin A in the intestinal mucosa or the liver, are also important determinants of carotenoid profile of the yolk (Poor et al., 1987 ; Hamilton, 1992 ; Gomez et al., 1978 ; Damron et al., 1984). In general, the liver is considered to be the main storage site for the carotenoids (Tyczkowski and Hamilton, 1986). It is interesting that in birds there is another major site for the deposition of carotenoids, the toe web, an integumentary site where lutein is present mainly in the esterified form (Tyczkowski and Hamilton, 1986). Also carotenoids probably are able to be transferred from this integumentary depot to the ovary at the onset of sexual maturity. The gradual loss of pigment from the shank and beak as egg production continues is also explained by the mobilisation of carotenoids for incorporation into yolk (Strand et al., 1998). Since lutein is transported in lipoproteins in the free alcohol form, its deposition in the toe web as lutein esters suggests the expression of specific enzymes which are responsible for esterification and this question needs further investigation. Carotenoids have been identified in integumentary structures such as feathers, bill, and feet of birds from about 19 families and 10 of the extant orders (Brush, 1981).

In primates and humans, adipose tissue is considered to be a primary storage depot for carotenoids (Rock et al., 1996) but the adrenal gland has the highest carotenoid concentration (Olson, 1993). In man, adipose tissue together with the liver account for at least $80 \%$ of carotenoid storage (Kaplan et al., 1990). Carotenoids are also found in other human tissues including skin, erythrocyte membrane, leukocytes, buccal mucosa and a variety of other tissues at autopsy (Thurnham, 1994).

In birds, carotenoids are also widely distributed among different tissues. In free living adult lesser black-backed gulls the highest carotenoid concentration $(45 \mu \mathrm{g} / \mathrm{g})$ was found in the liver; other tissues contained the following concentrations of 
carotenoids $(\mu \mathrm{g} / \mathrm{g})$ : kidney 8.2, pancreas 6.5 , heart 2.8 , abdominal fat 2.5 , lung and breast muscle 2.1 (Surai et al., $2000 \mathrm{~b}$ ). In contrast, in tissues of laying hens fed on a commercial wheat-barley diet, carotenoid concentrations were much lower $(\mu \mathrm{g} / \mathrm{g})$ : liver 6.2, abdominal fat 0.8 , kidney 0.7 , spleen 0.5 , heart 0.5 , lung 0.4 and muscle 0.2 (Surai et al., 1999). Even after dietary carotenoid supplementation, carotenoid concentrations in chicken tissues fell far short of the values for the gull (Surai et al., 1999). These data clearly show that there are substantial differences in the tissue carotenoid concentrations achieved by the wild gull and the domesticated chicken. It is interesting that the vitamin E levels in the gull tissues were also several times higher compared to the chicken although the level of $\alpha$-tocopherol in the egg yolk was very similar (Surai, 1999). In contrast, vitamin A accumulation in the gull liver (Surai et al., 2000 b) was comparable with that of the chicken (Surai et al., 1998 a). Species-specific features of carotenoid metabolism in birds require more study.

Our data indicate that, when laying hens were supplemented with dietary carotenoids for 4 weeks, the concentration of carotenoids in adipose tissue did not change significantly (Surai and Speake, 1998). This means that even if adipose tissue is a significant site of carotenoid deposition, this process is not very active in mature chickens (Surai et al., 1999). This conclusion is in agreement with a study of Negro et al. (2000), which suggests that, in wild geese, carotenoids present in the fat stores are not readily available for metabolic needs.

It is interesting to mention that strict carnivores rely on the diet containing pre-formed vitamin A and are not dependant on dietary carotenoid provision (van Vliet, 1996). On the other hand, strict herbivores depend on carotenoid provision to synthesise vitamin A. Furthermore, animals with yellow fat such as humans and cattle effectively accumulate carotenoids in this tissue, whereas white-fat animals such as rabbits, pigs, guinea pigs and sheep do not accumulate carotenoids in their adipocytes (van Vliet, 1996 ; Williams, 1992). In addition, ruminants absorb almost no oxycarotenoids and therefore rely solely on carotenes (Hencken, 1992). Birds, as mentioned above, are good converters of $\beta$-carotene to vitamin A (Poor et al., 1987) and in most cases accumulate mainly oxycarotenoids in the tissues.

As mentioned above, a bird's ability to oxidise or reduce carotenoids, or to inerconvert the end rings of the carotenoid molecule, is an additional factor in carotenoid compositional variability in feathers, skin and probably in the egg yolk as well. This includes the synthesis of canthaxanthin, astaxanthin, canary-xanthophylls, rhodoxin-like pigments and some others. In addition, chickens can acylate and deacylate lutein in the intestinal tract, liver and integument and can reduce oxocarotenoids to their corresponding alcohols or oxidize lutein to $3^{\mathrm{I}}$-oxolutein (Tyczkowski et al., 1986). Furthermore, the following routs of carotenoid interconversion in birds have been suggested recently by Stradi (1998) :

1) $\quad \beta$-carotene $\rightarrow$ echinenone $\rightarrow$ canthaxanthin or / and 3-hydroxy-echinenone $\rightarrow$ adonirubin $\rightarrow$ astaxanthin

2) $\beta$-cryptoxanthin $\rightarrow$ 3-hydroxy-echinenone $\rightarrow$ adonirubin $\rightarrow$ astaxanthin

3) Lutein $\rightarrow$ canary xanthophyll $\mathrm{A} \rightarrow$ canary xanthophyll B 
4) zeaxanthin $\rightarrow$ 3-dehydrolutein $\rightarrow$ canary xanthophyll B

5) zeaxanthin $\rightarrow$ adonixanthin $\rightarrow$ astaxanthin

The enzymes responsible for the transformation of carotenoids in birds are not characterised at present. It has been suggested that monooxygenases, dehydrogenases and mixed function oxidases could be involved in such processes (Hudon, 1994) but more work is needed to understand the regulatory mechanisms of carotenoid interconversion in birds.

These conversions of carotenoids start from 4 major carotenoids available in the diet of most birds in the wild or in captivity ; namely, $\beta$-carotene (green leaves, alfalfa), $\beta$-cryptoxanthin (maize, maize gluten), lutein (all major feeds including maize, wheat, barley, green leaves, alfalfa, marigold etc.) and zeaxanthin (maize, maize gluten etc.). In the wild, fish-eating and crustacean-eating birds can obtain many carotenoids including canthaxanthin and astaxanthin from fish and sea products and other types of birds can obtain a range of carotenoids from other natural sources. In contrast, in captivity when carotenoid sources are limited in variety, the above routes of carotenoid interconversion could play a crucial role for maintaining plumage colour. However, it has been shown that several species of birds became pale in captivity, irrespective of carotenoid supplementation (Hudon, 1994) indicating that environmental conditions could be among major factors regulating carotenoid metabolism in birds.

\section{Conclusions}

The presented information clearly shows that the provitamin A activity of natural carotenoids is a minor issue for the poultry industry. A more important matter is to understand the other biological functions of carotenoids and their relevance to embryonic development. In this respect the chicken is characterised by the almost exclusive accumulation of xanthophylls with only traces of $\beta$-carotene found in the chicken egg yolk and plasma. By contrast, our recent results reveal the presence of high proportions (up to $30 \%$ of total carotenoids) of $\beta$-carotene in the egg yolk of several avian species, including gull, moorhen and coot. This finding needs more detailed investigation.

In most avian species in the wild, carotenoid concentrations in the egg yolk are several times higher in comparison to the commercial chicken. This raises a question wheather carotenoid concentration in the wheat-barley based chicken diet is adequate to maintain specific physiological functions where carotenoids are shown to participate. This could include immune function, antioxidant protection and probably other so far unidentified functions of carotenoids.

Most previous work in poultry has concentrated on the effects of carotenoids on yolk colour to maintain high consumer acceptance of table eggs. However the role of carotenoids in embryonic development remains unclear and warrants further study.

Our recent results in relation to antioxidant properties of carotenoids during chicken embryonic development suggest that these properties of carotenoids could be a background for understanding a role of carotenoids as natural protectants responsible for the prevention of lipid peroxidation in the embryonic tissues, particularly during hatching. 
Taking into account that in the wild carotenoids could be more easily available than other antioxidants such as vitamin $\mathrm{E}$ we can suggest that the antioxidant system of the avian embryo could be based on high carotenoid concentrations and therefore the embryo and newly hatched chick could benefit from increased levels of carotenoids in the egg yolk.

\section{Acknowledgements}

The authors are grateful to the Scottish Executive Rural Affairs Department for financial support and to the World Poultry Science Association for the Science Award for PFS.

\section{References}

Alam AV, Couch JR and Greger CR. The carotenoids of the marigold, Tagetes erecta. Canadian Journal of Botany, $46: 1539-1541.1968$.

Annison EF. Lipid Metabolism. In : Physiology and Biochemistry of the Domestic Fowl (Freeman BM ed). Vol. 4. pp. 165-174. Academic Press. London.1983.

Armstrong GA. Genetics of eubacterial carotenoid biosynthesis : a colourful tale. Annual Review of Microbiology, 51 : 629-659. 1997.

Bartov I and Bornstein S. Comparisons of BHT and ethoxyquin as antioxidants in the nutrition of broilers. Poultry Science. $51: 859-869.1972$.

Belyavin CG and Marangos AG. Natural products for egg yolk pigmentation. In : Recent Advances in Poultry Nutrition (Cole DJA and Haresign W eds). pp. 239-260, Butterworths. 1989.

Bendich A. Beta-carotene and the immune response. Proceedings of Nutrition Society, $50: 263$ $-274.1991$.

Bendich A and Olson JA. Biological actions of carotenoids. FASEB Journal, 3 : 1927-1932. 1989.

Bertram JS and Borthiewicz H. Dietary carotenoids inhibit neoplastic transformation and modulate gene expression in mouse and human cells. American Journal of Clinical Nutrition, 62:1327-1336. 1995.

Bicoff EM, Livingston AL, Bailey GF and Thompson CR. Xanthophylls in fresh and dehydrated alfalfa. Journal of Agricultural and Food Chemistry, $2:$ 563-567. 1954.

Bieri JG and Farrell PM. Vitamin E. Vitamin and Hormone, 34 : 31-75. 1976.

Boileau TW, Clinton SK and Erdman JW Jr. Tissue lycopene concentrations and isomer patterns are affected by androgen status and dietary lycopene concentration in male F 344 rats. Journal of Nutrition, $130: 1613-1618.2000$.

Bortolotti GR, Negro JJ, Tella JL, Marchant TA and Bird DM. Sexual dichromatism in birds independent of the diet, parasites and androgens. Proceedings of the Royal Society of London, 263 : 1171-1176. 1996.

Britton G. Structure and properties of carotenoids in relation to function. FASEB Journal, 9 : 1551-1558. 1995.

Brush AH. Metabolism of carotenoid pigments in birds. FASEB Journal, 4 : 2969-2977. 1990.

Brush AH. Carotenoids in wild and captive birds. In : Carotenoids as colorants and vitamin A precursors (Bauernfeind JC ed.). pp. 539-562. Academic Press, New York-London. 1981.

Burton GW. Antioxidant actions of carotenoids. Journal of Nutrition, 119 : 109-111. 1989.

Canfield LM, Valenzuela JG and Forage JW. Metabolism of carotenoids by enzymes of oxygen metabolism. In : Lipid-Soluble antioxidants : biochemistry and clinical applications. (Ong ASH and Packer L eds.). pp. 193-207. Birkhauser Verlag, Basel. 1992.

Castenmiller JJ, Lauridsen ST, Dragsted LO, van het Hof KH, Linssen JP and West CE. Beta-carotene does not change markers of enzymatic and nonenzymatic antioxidant activity in human blood. Journal of Nutrition, $129: 2162-2169.1999$. 
Castenmiller JJ and West C. Bioavailability and bioconversion of carotenoids. Annual Review of Nutrition, $18: 19-38.1998$.

Chan AC, Chow CK and Chiu D. Interaction of antioxidants and their implication in genetic anemia. Proceedings of the Society for Experimental Biology and Medicine, 222 : 274-282. 1999.

Cheng ALS and Deuel HJ Jr. Studies on carotenoid metabolism. X. The site of the conversion of carotene to vitamin A in the chick. Journal of Nutrition, $41: 619-627.1950$.

Clark RM, Yao L, She L and Furr HC. A comparison of lycopene and canthaxanthin absorption : using the rat to study the absorption of non-provitamin A carotenoids. Lipids, $33: 159$ 163. 1998.

Cohn W. Bioavailability of vitamin E. European Journal of Clinical Nutrition, 51: S80-S85. 1997.

Combs GF Jr. Mechanisms of absorption, transport and tissue uptake of vitamin E. In : Vitamin $\mathrm{E}$ in animal nutrition and management. A BASF Reference Manual (Coelho MB ed.). pp. 27-35. BASF Corporation. New York. 1996.

Coon CN and Couch JR. Effect of storage and fatty acid esters on the utilization of xanthophyll from marigold meal by laying hens. Poultry Science, $55:$ 841-847. 1976.

Damron BL, Goodson SR, Harms RH, Janky DM and Wilson HR. $\beta$-carotene supplementation of laying hen diet. British Poultry Science, 25 : 349-352. 1984.

Davison A, Rousseau E and Dunn B. Putative anticancerogenic actions of carotenoids: nutritional implications. Canadian Journal of Physiology and Pharmacology, 71 : 732-745. 1993.

Dua PN, Day EJ, Hill JE and Grogan CO. Utilization of xanthophylls from natural sources by the chick. Journal of Agricultural and Food Chemistry, $15: 324-328.1967$.

Edge R, McGarvey DJ and Truscott TG. The carotenoids as anti-oxidants - a review. Journal of Photochemistry and Photobiology, 41 B : 189-200. 1997.

Erdman JW Jr, Bierer TL and Gugger ET. Absorption and transport of carotenoids. Annals of New York Academy of Science, 691: 76-85. 1993.

Fletcher DL. An avaluation of the AOAC method of yolk colour analyses. Poultry Science, 59 : 1059-1066. 1980.

Fox DL, Wolfson AA and McBeth JW. Metabolism of $\beta$-carotene in the American Flamingo, Phoenicopterus ruber. Comparative Biochemistry and Physiology, 29 : 1223-1229. 1969.

Fox DL, Hopkins TS and Zilvermit DL. Blood carotenoids of the roseate sponbill. Comparative Biochemistry and Physiolpgy, $14: 641-649.1965$.

Frigg M, Whitehead CC and Weber S. Absence of effects of dietary alpha-tocopherol on egg yolk pigmentation. British Poultry Science, 33 : 347-353. 1992.

Furr HC and Clark RM. Intestinal absorption and tissue distribution of carotenoids. Journal of Nutritional Biochemistry, $8: 364-377.1997$.

Ganguly J, Mehl JW and Deuel HJ. Studies on carotenoid metabolism. XII. The effect of dietary carotenoids on the carotenoid distribution in the tissues of the chicken. Journal of Nutrition, $50: 59-72.1953$.

Gartner C, Stahl W and Sies H. Preferential increase in chylomicron levels of the xanthophylls lutein and zeaxanthin compared to beta-carotene in the human. International Journal for Vitamin and Nutrition Research, $66: 119-125.1996$.

Gomez R, Alonso A and Martin M. Carotenoid absorption in chick intestine. Review of Espanol Fisiology, 34 : 257-259. 1978.

Goodwin TW. Distribution of carotenoids. In : Methods in Enzymology., Carotenoids : Part A. Chemistry, Separation, Quantitation and Antioxidation. (Packer L ed.). Vol. 213. pp. 167172. Academic Press. New York. 1992.

Goodwin TW. The Biochemistry of the carotenoids. Volume II Animals. Chapman and Hall, London-New York. 1984.

Grolier P, Duszka C, Borel P, Alexandre-Gouabau MC, Azais-Braesco V. In vitro and in vivo inhibition of beta-carotene dioxygenase activity by canthaxanthin in rat intestine. Archives 
of Biochemistry and Biophysics, $348: 233-238.1997$.

Hamilton PB. The use of high-performance liquid chromatography for studying pigmentation. Poultry Science, $71: 718^{-724} .1992$.

Hamilton PB and Parkhurst CR. Improved deposition of oxycarotenoids in egg yolks by dietary cottonseed oil. Poultry Science, 69 : 354-359. 1990.

Hamilton PB, Tirado FJ and Garcia-Hernandez F. Deposition in egg yolks of carotenoids from saponified and unsaponified oleoresin of red pepper (Capsicum annuum) fed to laying hens. Poultry Science, $69: 462-470.1990$.

Handelman GJ, Nightingale ZD, Lichtenstein AH, Schaefer EJ and Blumberg JB. Lutein and zeaxanthin concentrations in plasma after dietary supplementation with egg yolk. American Journal of Clinical Nutrition, $70: 247-251.1999$.

Haq AU, Bailey CA and Chinnah AD. Neonatal immune response and growth performance of chicks hatched from Single Comb White Leghorn breeders fed diet supplemented with $\beta$-carotene, canthaxanthin, or lutein. Poultry Science, $74: 844-851.1995$.

Hencken H. Chemical and physiological behavior of feed carotenoids and their effects on pigmentation. Poultry Science, 71: 711-717. 1992.

Herbst S, Bowen P, Hussain E, Stecewicz-Sapuntzakis M, Damayanti B, Burns J. Evaluation of the bioavailability of lutein (L) and lutein diesters (LD) in humans. FASEB Journal, 11 : A 447. 1997.

Hill GE. Interspecific variation in plasma hue in relation to carotenoid plumage pigmentation. Auk, 112 : 1054-1057. 1995.

Hill GE. Is there an iummunological cost to carotenoid-based ornamental coloration. American Naturalist, $5:$ :589-595. 1999.

Hinton CF, Fry JL and Harms RH. Influence of xanthophyll-free pullet grower diet on subsequent egg yolk pigmentation. Poultry Science, 53 : 223-226. 1974.

Hollander D. Intestinal absorption of vitamins A, E, D, and K. Journal of Laboratory and Clinical Medicine, 97 : 449-462. 1981.

Hudon J. Biotechnological applications of research on animal pigmentation. Biotechnology Advances, $12: 49-69.1994$.

Hughes DA. Effects of carotenoids on human immune function. Proceedings of the Nutrition Society, $58:$ 713-718. 1999.

Hurwitz S, Bar A, Katz M, Sklan D and Budowski P. Absorption and secretion of fatty acids and bile acids in the intestine of the laying fowl. Journal of Nutrition, 103: 543-547. 1973.

Isler O. Introduction. In : Carotenoids (Isler O, Gutmann H and Solm U eds). pp. 11-27. Birkhauser Verlag. Basel. 1971.

Jensen A. The effect of seaweed carotenoids on egg yolk coloration. Poultry Science, 42: 912916. 1963.

Jiang YH, McGeachin and Bailey CA. $\alpha$-Tocopherol, $\beta$-carotene and retinol enrichment of chicken eggs. Poultry Science, 73 : 1137-1143. 1994.

Johnson EJ, Qin J, Krinsky NI and Russell RM. Ingestion by men of a combined dose of beta-carotene and lycopene does not affect the absorption of beta-carotene but improves that of lycopene. Journal of Nutrition, $127: 1833-1837.1997$.

Johnson EA, Lewis MJ and Grau CR. Pigmentation of egg yolks with astaxanthin from the yeast Phaffia rhodozyma. Poultry Science, $59: 1777-1782.1980$.

Kaplan LA, Lau JM and Stein EA. Carotenoid composition, concentrations, and relationships in various human organs. Clinical Physiology and Biochemistry, 8 : 1-10. 1990.

Karnaukhov VN. Carotenoids : recent progress, problems and prospects. Comparative Biochemistry and Physiology, 95 B : 1-20. 1990.

Krinsky NI. Carotenoids in medicine. In : Carotenoids : Chemistry and Biology (Krinsky NI, Mathews-Roth MM and Taylor RF eds.). pp. 279-291.Plenum Press, New York and London. 1989.

Krinsky NI. Antioxidant functions of carotenoids. Free Radical Biology and Medicine, 7 : 617635. 1989 a.

Krinsky NI. Effects of carotenoids in cellular and animal systems. American Journal of Clinical 
Nutrition, 53 : 238S-246S. 1992.

Krinsky NI. The biological properties of carotenoids. Pure and Applied Chemistry, 66 : $1003^{-}$ 1010. 1994.

Krogdahl A. Digestion and absorption of lipids in poultry. Journal of Nutrition, $115: 675-685$. 1985.

Kuhn R and Brockman H. Bestimmung von carotinoiden. Hoppe-Seyler's Journal of Physiological Chemistry, $206:$ 41-64. 1932.

Kuhn R, Winterstain A and Lederer E. Zur Kenntris der xanthophylls. Journal of Physiological Chemistry, 197 : 141-160. 1931.

Kuzmicky DD, Kohler GO, Livigston AL, Knowles RE and Nelson JW. Broiler pigmentation potency of neoxanthin and violaxanthin relative to lutein. Poultry Science, $48: 326^{-330 .}$ 1969.

Livingston AL, Kuzmicky DD, Knowles RE and Cohler GO. The nature and deposition of the carotenoids from alfalfa and corn gluten meal in chicken skin. Poultry Science, $48: 1678^{-}$ 1683. 1969.

Marusich W, DeRitter E and Bauernfeind JC. Evaluation of carotenoid pigments for coloring yolks. Poultry Science, $39: 1338-1345.1960$.

Marusich WL and Bauernfeind JC. Oxycarotenoids in poultry feeds. In : Carotenoids as colorants and vitamin A precursors (Bauernfeind JC ed.). pp. 320-462. Academic Press, New York-London. 1981.

Matsuno T. Animal carotenoids. In : Carotenoids : Chemistry and biology (Krinsky NI, Mathews-Roth MM and Taylor RF eds.). pp. 59-74. Plenum Press, New York and London. 1989.

Middendorf DF, Childs GR and Cravens WW. Variation in the biological availability of xanthophyll within and among genetic resouces. Poultry Science, $59: 1460-1470.1980$.

Middendorf DF, Childs GR and Cravens WW. A rapid bioassay for the comparison of xanthophyll availability from various sources. Poultry Science, $59: 1442-1450.1980 \mathrm{a}$.

Nakaue HS, Kurnick AA, Hulett BJ and Reid BL. Effect of ethoxyquin on carotene stability and utilization. Poultry Science, $45: 478-483.1966$.

Negro JJ, Figuerola J, Garrido J and Green AJ. Fat stores in birds : an overlooked sink for carotenoid pigment. Functional Ecology, 2000. (Submitted).

Negro JJ, Bortolotti GR, Tella JL, Fernie KJ and Bird DM. Regulation of integumentary colour and plasma carotenoids in American Kestrels consistent with sexual selection theory. Functional Ecology, $12:$ 307-312. 1998.

Negro JJ, Tella JL, Blanco G, Forero MG and Garrido-Fernandez J. Diet explains interpopulation variation of plasma carotenoids and skin pigmentation in nestling white storks. Physiological and Biochemical Zoology, 73 : 97-101. 2000 a.

Niki E. $\alpha$-Tocopherol. In : Handbook of antioxidants (Cadenas E and Packer L eds.). pp. 3-25. Marcel Dekker. New York. 1996.

Nys Y. Dietary carotenoids and egg yolk coloration - a review. Archive Geflugelk, 64 : 45-54. 2000.

Olson JA. Provitamin A function of carotenoids : The conversion of the $\beta$-carotene into vitamin A. Journal of Nutrition, $119: 105-108.1989$.

Olson JA. Carotenoids and vitamin A : an overview. In : Lipid-Soluble antioxidants : biochemistry and clinical applications. (Ong ASH and Packer L eds.). pp. 178-192. Birkhauser Verlag, Basel. 1992.

Olson JA. Vitamin A and carotenoids as antioxidants in a physiological context. Journal of Nutritional Science and Vitaminology (Tokyo), 39 Suppl : S57-S65. 1993.

Ong ASH and Tee ES. Natural sources of carotenoids from plants and oils. In : Methods in Enzymology. Vol. 213, Carotenoids : Part A. Chemistry, Separation, Quantitation and Antioxidation. (Packer L ed.). pp. 142-167. Academic Press, New York. 1992.

Palmer LS. Xanthophyll, the principal natural yellow pigment of the egg yolk, body fat and blood serum of the hen. The physiological relationship of the pigments to the xanthophylls of plants. Journal of Biological Chemistry, $23: 261-279.1915$. 
Palmer LS and Kempster HL. The influence of specific feed and certain pigments on the colour of the egg yolk. Journal of Biological Chemistry, 39:331-337. 1919.

Parker RS, Swanson JE, You CS, Edwards AJ, Huang T. Bioavailability of carotenoids in human subjects. Proceedings of the Nutrition Society, 58 : 155-162. 1999.

Pfander H. Carotenoids : An overview. In : Methods in Enzymology. Carotenoids : Part A. Chemistry, Separation, Quantitation and Antioxidation. (Packer L ed.). Vol. 213, pp. 3-13. Academic Press, New York.1992.

Philip T and Berry JW. Nature of lutein acylation in marygold (Tagetes erecta) flowers. Journal of Food Science $40: 1089-1090.1975$.

Philip T, Weber CW and Berry JW. Utilization of lutein and lutein-fatty acid esters by laying hens. Journal of Food Science, $41: 23-25.1976$.

Poor CL, Miller SD, Fahey GC, Easter RA and Erdman JW. Animal models for carotenoid utilization studies : evaluation of the chick and the pig. Nutrition Reports International, 36 : 229-234. 1987.

Quackenbush FW. Xanthophylls and carotenes in feeds and feed materials : collaborative study. Journal of Association of Analytical Chemistry, 53 : 186-189. 1970.

Quackenbush FW, Firch JG, Rabourn WJ, McQuistan M, Petzold EN and Kargl TE. Analysis of carotenoids in corn grain. Journal of Agricultural and Food Chemistry, 9:132-135. 1961.

Rice-Evans CA, Samson J, Bramley PM and Holloway DE. Why do we expect carotenoids to be antioxidants in vivo? Free Radical Research, $26: 381-398.1997$.

Rock CL. Carotenoids : Biology and treatment. Pharmacology \& Therapeutics, $75: 185-197$. 1997.

Rock CL, Kusluski RA, Galvez MM and Ethier SP. Carotenoids induce morphological changes in human mammary epithelial cell cultures. Nutrition and Cancer $23: 319-333.1995$.

Rock CL, Fada RD, Jacob RA and Bowen PI. Update on the biological characteristics of the antioxidant micronutrients : Vitamin $\mathrm{C}$, vitamin $\mathrm{E}$, and the carotenoids. Journal of the American Dietetic Association, 96 : 693-702. 1996.

Roodenburg AJ, Leenen R, van Het Hof KH, Weststrate JA and Tijburg LB. Amount of fat in the diet affects bioavailability of lutein esters but not of alpha-carotene, beta-carotene, and vitamin E in humans. American Journal of Clinical Nutrition, 71 : 1187-1193. 2000.

Royle NJ, Surai PF, McCartney RJ and Speake BK. Parental investment and egg yolk lipid composition in gulls. Functional Ecology, 13 : 298-306. 1999.

Saino N, Stradi R, Ninni P and Moller AP. Carotenoid plasma concentration, immune profile and plumage ornamentation of male barn swallows (Hirundo rustica). American Naturalist, 154 : 441-448. 1999.

Schaeffer JL, Tyczkowski JK, Parkhurst CR and Hamilton PB. Carotenoid composition of serum and egg yolks of hens fed varying in carotenoid composition. Poultry Science, 67 : 608-614. 1988.

Schiedt K. New aspects of carotenoid metabolism in animals. In : Carotenoids : Chemistry and biology. (Krinsky NI, Mathews-Roth MM and Taylor RF eds.). pp. 247-268, Plenum Press, New York and London. 1989.

Schiedt K, Leuenberger FJ, Vecchi M and Glinz E. Absorption, retention and metabolic transformations of carotenoids in raunbow trout, salmon and chicken. Pure and Applied. Chemistry, $57: 685-692.1985$.

Schweigert FJ, Wierich M, Rambeck WA, Zucker H. Carotene cleavage activity in bovine ovarian follicles. Theriogenology, $30: 923-930.1988$.

Simpson KL and Chichester CO. Metabolism and nutritional significance of carotenoids. Annual Reviews of Nutrition, $1: 351-374.1981$.

Sklan D, Shachaf B, Baron J and Hurwitz S. Retrograde movement of digesta in the duodenum of the chick : extent, frequency, and nutritional implications. Journal of Nutrition, 108 : 1485-1490. 1978.

Slifka KA, Bowen PE, Stacewicz-Sapuntzakis M and Crissey SD. A survey of serum and dietary carotenoids in captive wild animals. Journal of Nutrition, 129:380-390. 1999. 
Socaciu C, Jessel R and Diehl HA. Competitive carotenoid and cholesterol incorporation into liposomes : effects on membrane phase transition, fluidity, polarity and anisotropy. Chemistry and Physics of Lipids, $106: 79-88.2000$.

Smith ID and Perdue HS. Isolation and tentative identification of the carotenoids present in chicken skin and egg yolks. Poultry Science, $45: 577-581.1966$.

Speake BK, Decrock F, Surai PF, Groscolas R. Fatty acid composition of the yolk lipids of a fish-eating bird, the Emperor Penguin (Aptenodytes forsteri). Lipids, 4 : 283-290. 1999.

Speake BK, Surai PF, Noble RC, Beer JV and Wood N. Differences in egg lipid and antioxidant composition between wild and captive pheasants and geese. Comparative Biochemistry and Physiology, 124 B : 101-107. 1999a.

Speake BK, Surai PF and Gore M. Lipid Composition, Fatty Acid Profiles and Lipid-Soluble Antioxidants of Eggs of the Herman's Tortoise (Testudo hermanni). Zoo Biology, 2000 (Submitted).

Stahl $\mathrm{W}$ and Sies H. Physical quenching of singlet oxygen and cis-trans isomerization of carotenoids. Annals of the New York Academy of Sciences, 691 : 10-19. 1993.

Stevens L. Avian biochemistry and molecular biology. Cambridge University Press, Cambridge. 1996.

Stradi R. The colour of flight. Solei Gruppo Editoriale Informatico, Milan. 1998.

Strand A, Herstad O and Liaaen-Jensen S. Fucoxanthin metabolites in egg yolks of laying hens. Comparative Biochemistry and Physiology, 119 A : 963-974. 1998.

Subczynski WK, Markowska E and Sielewiesiuk J. Spin-label studies on phosphatidylcholinepolar carotenoid membranes : effects of alkyl-chain length and unsaturation. Biochimica et Biophysica Acta, 1150 : 173-181. 1993.

Surai PF. Vitamin E in avian reproduction. Poultry and Avian Biology Reviews, 10 : 1-60. 1999.

Surai PF. Tissue-specific changes in the activities of antioxidant enzymes during the development of the chicken embryo. British Poultry Science, $40: 397-405.1999$ a.

Surai PF. Organic selenium : benefits to animals and humans, a biochemist's view. In : Biotechnology in the Feed industry. Proc. Alltech's 16th Annual Symposium (T. P. Lyons and K. A. Jacques, eds.). pp. 205-260. Nottingham University Press, Nottingham. 2000.

Surai PF. Effect of selenium and vitamin E content of the maternal diet on the antioxidant system of the yolk and the developing chick. British Poultry Science, 41:235-243. 2000 a.

Surai PF, Bortolotti GR, Fidgett A, Blount J and Speake BK. Effects of piscivory on the fatty acid profiles and antioxidants of avian yolk : studies on eggs of the gannet, skua, pelican and cormorant. Journal of Zoology, London, (in press). 2000.

Surai P, Ionov I, Kuchmistova E, Noble RC and Speake BK. The relationship between the levels of $\alpha$-tocopherol and carotenoids in the maternal feed, yolk and neonatal tissues : Comparison between the chicken, turkey, duck and goose. Journal of Science in Food and Agriculture, $76: 593-598.1998$.

Surai PF, Ionov IA, Kuklenko TV, Kostjuk IA, MacPherson A, Speake BK, Noble RC and Sparks NHC. Effect of supplementing the hen's diet with vitamin A on the accumulation of vitamins $\mathrm{A}$ and $\mathrm{E}$, ascorbic acid and carotenoids in the egg yolk and in the embryonic liver. British Poultry Science, $39: 257-263.1998$ a.

Surai PF, MacPherson A, Speake BK and Sparks NHC. Designer egg eveluation in a controlled trial. European Journal of Clinical Nutrition, $54: 298-305.2000$ a.

Surai PF, McDevitt RM, Speake BK and Sparks NHC. Carotenoid distribution in tissues of the laying hen depending on their dietary supplementation. Proceddings of the Nutrition Society, $58: 30$ A. 1999.

Surai PF, Noble RC and Speake BK. Tissue-specific differences in antioxidant distribution and susceptibility to lipid peroxidation during development of the chick embryo. Biochimica et Biochysica Acta, 1304 : 1-10. 1996.

Surai PF, Royle NK and Sparks NHC. Fatty acid, carotenoid and vitamin A composition of tissues of free living gulls. Comparative Biochemistry and Physiology,126 A : 387-396. $2000 \mathrm{~b}$.

Surai PF and Sparks NHC. Comparative evaluation of the effect of two maternal diets on fatty 
acids, vitamine $\mathrm{E}$ and carotenoids in the chick embryo. British Poultry Science, (in press). 2000.

Surai PF and Speake BK. Distribution of carotenoids from the yolk to the tissues of the chick embryo. Journal of Nutritional Biochemistry, 9 : 645-651. 1998.

Surai PF, Speake BK, Wood NAR, Blount JD, Bortolotti GR and Sparks NHC. Carotenoid discrimination by the avian embryo : A lesson from wild birds. Comparative Biochemistry and Physiology. (in press). $2000 \mathrm{c}$.

Tee E-S. Carotenoids and retinoids in human nutrition. Critical Reviews in Food Science and Nutrition, 31 : 103-163. 1992.

Tella JL, Negro JJ, Rodriguez-Estrella R, Blanco G, Forero MG, Blazquez MC and Hiraldo F. A comparison of spectrophotometry and color charts for evaluating total plasma carotenoids in wild birds. Physiological Zoology, 71 : 708-711. 1998.

Thompson MB, Speake BK, Russel KJ, McCartney RJ and Surai PF. Changes in fatty acid profiles and in protein, ion and energy contents of eggs of the Murray Short-Necked Turtle, Emydura macquarii (Chelonia, Pleurodira) during development. Comparative Biochemistry and Physiology, $122 \mathrm{~A}$ : 75-84. 1999 a.

Thompson MB, Speake BK, Stewart JR, Russel KJ, McCartney RJ and Surai PF. Placental nutrition in the viviparous lizard Niveoscincus metallicus : the influence of placental type. Journal of Experimental Biology ; 202 (Pt 21) : 2985-2992. 1999 b.

Thompson MB, Stewart JR, Speake BK, Russel KJ, McCartney RJ and Surai PF. Placental nutrition in a viviparos lizard with a complex placenta. Journal of Zoology, London, 248 : 295-305. 1999 c.

Thurnham DI. Carotenoids : functions and fallacies. Proceedings of the Nutrition Society, 53 : 77-87. 1994.

Thurnham DI and Northrop-Clewes CA. Optimal nutrition : vitamin A and carotenoids. Proceedings of the Nutrition Society, 58 : 449-457. 1999.

Traber MG. Biokinetics of vitamin E. In : Handbook of antioxidants (Cadenas E and Packer L eds.). pp. 43-61. Marcel Dekker, New York. 1996.

Traber MG, Lane JC, Lagmay N and Kayden HJ. Studies on the transfer of tocopherol between lipoproteins. Lipids, 27 : 657-663. 1992.

Trams EG. Carotenoid transport in the plasma of the scarlet ibis (Eudocimus ruber). Comparative Biochemistry and Physiology, $8: 1177-1184.1969$.

Tyczkowski JK and Hamilton PB. Absorption, transport, and deposition in chickens of lutein diester, a carotenoid extracted from marigold (Tagetes erecta) petals. Poultry Science, 65 : 1526-1531. 1986.

Tyczkowski JK and Hamilton PB. Evidence for differential absorption of zeacarotene, cryptoxanthin and lutein in young broiler chickens. Poultry Science, 65: 11137-1140. $1986 \mathrm{~b}$.

Tyczkowski JK, Schaeffer JL, Parkhurst C and Hamilton PB. 3'-Oxolutein, a metabolite of lutein in chickens. Poult. Science, 65 : 2135-2141. 1986.

Umegaki K, Aoshima M, Hirota S, Uramoto H and Esashi T. Simultaneous dietary supplementation of sodium cholate and beta-carotene markedly enhances accumulation of beta-carotene in mice. Journal of Nutrition, 125 : 3081-3086. 1995.

van den Berg $\mathbf{H}$. Effect of lutein on beta-carotene absorption and cleavage. International Journal for Vitamin and Nutrition Research,. 68 : 360-365. 1998.

van het Hof KH, Brouwer IA, West CE, Haddeman E, Steegers-Theunissen RP, van Dusseldorp M, Weststrate JA, Eskes TK and Hautvast JG. Bioavailability of lutein from vegetables is 5 times higher than that of $\beta$-carotene. American Journal of Clinical Nutrition, 70 : 261-268. 1999.

van het Hof KH, West CE, Weststrate JA. and Hautvast JGAJ. Dietary factors that affect the bioavailability of carotenoids. Journal of Nutrition, $130: 503-506.2000$.

van het Hof KH, Tijburg LB, Pietrzik $\mathrm{K}$ and Weststrate JA. Influence of feeding different vegetables on plasma levels of carotenoids, folate and vitamin C. Effect of disruption of the vegetable matrix. British Journal of Nutrition, 82 : 203-212. 1999 a. 
van Vliet T. Absorption of $\beta$-carotene and other carotenoids in humans and animal models. European Journal of Clinical Nutrition, 50 : S32-S37. 1996.

Walzem RL. Lipoproteins and the laying hen : Form follows function. Poultry and Avian Biology Reviews, 7 : 31-64. 1996.

Wang XD, Tang GW, Fox JG, Krinsky NI and Russell RM. Enzymatic conversion of betacarotene into beta-apo-carotenals and retinoids by human, monkey, ferret, and rat tissues. Archives of Biochemistry and Biophysics, $285:$ 8-16. $^{-1991 .}$

Weiser $\mathrm{H}$ and Kormann A. Provitamin A activities and physiological functions of carotenoids in animals. Relevance to human health. In : Annals of the New York Academy of Sciences. Carotenoids in Human Health (Canfield LM, Krinsky NI and Olson JA eds.). Vol. 691, pp. 213-215, New York Academy of Science, New York. 1993.

Westergaard $\mathbf{H}$ and Dietschy JM. The mechanism whereby bile acid micelles increase the rate of fatty acid and cholesterol uptake into the intestinal mucosal cell. Journal of Clinical Investigation, $58:$ 97-108. 1976.

White WS, Peck KM, Bierer TL, Gugger ET and Erdman JW Jr. Interactions of oral betacarotene and canthaxanthin in ferrets. Journal of Nutrition, $123: 1405-1413.1993$.

White WS, Stacewicz-Sapuntzakis M, Erdman JW Jr and Bowen PE. Pharmacokinetics of beta-carotene and canthaxanthin after ingestion of individual and combined doses by human subjects. Journal of the American College of Nutrition, 13:665-671. 1994.

Williams WD. Origin and impact of colour on consumer preference for food. Poultry Science, 71 : 744-746. 1992.

Williams AW, Boileau TWM and Erdman JW Jr. Factors influencing the uptake and absorption of carotenoids. Proceedings of the Society of Experimental Biology and Medicine, $218: 106$ $-108.1998$.

Williams WP, Davies RE and Couch JR. The utilization of carotenoids by the hen and chick. Poultry Science, 42 : 691-699. 1963.

Woodall AA, Britton $G$ and Jackson MJ. Antioxidant activity of carotenoids in phosphatidylcholine vesicles : chemical and structural considerations. Biochemical Society Transactions, $23: 133$ S. 1995.

Woodall AA, Britton G and Jackson MJ. Dietary supplementation with carotenoids : effects on alpha-tocopherol levels and susceptibility of tissues to oxidative stress. British Journal of Nutrition, $76:$ 307-317. 1996.

Zhang LX, Cooney RV and Bertram JS. Carotenoids enhance gap junction communication and inhibit lipid peroxidation in $\mathrm{C} 3 \mathrm{H} / 1 \mathrm{O} \mathrm{T} 1 / 2$ cells : relationship to the cancer chemopreventative action. Carcinogenesis, $12: 2109-2114.1991$.

Zhang LX, Cooney RV and Bertram JS. Carotenoids up-regulate connexin 43 gene expression independent of pro-vitamin A or antioxidant properties. Cancer Research, 52 : 5707-5712. 1992. 